\title{
Bioactivities of Compounds from Elephantopus scaber, an Ethnomedicinal Plant from Southwest China
}

\author{
Jianjun Wang, 1 Ping Li, ${ }^{1}$ Baosai Li, ${ }^{2}$ Zhiyong Guo, \\ Edward J. Kennelly, ${ }^{1,3}$ and Chunlin Long ${ }^{1,4}$ \\ ${ }^{1}$ College of Life and Environmental Sciences, Minzu University of China, 27 Zhong-Guan-Cun South Avenue, \\ Haidian District, Beijing 100081, China \\ ${ }^{2}$ School of Chinese Materia Medica, Beijing University of Chinese Medicine, 11 Third Ring Road, \\ Chaoyang District, Beijing 100029, China \\ ${ }^{3}$ Department of Biological Science, Lehman College, and Graduate Center, City University of New York, \\ 250 Bedford Park Boulevard West, Bronx, NY 10468, USA \\ ${ }^{4}$ Kunming Institute of Botany, Chinese Academy of Sciences, 132 Lanhei Road, Kunming 650201, China
}

Correspondence should be addressed to Chunlin Long; long@mail.kib.ac.cn

Received 2 April 2014; Accepted 30 April 2014; Published 19 May 2014

Academic Editor: Shi-Biao Wu

Copyright (C) 2014 Jianjun Wang et al. This is an open access article distributed under the Creative Commons Attribution License, which permits unrestricted use, distribution, and reproduction in any medium, provided the original work is properly cited.

Elephantopus scaber is an ethnomedicinal plant used by the Zhuang people in Southwest China to treat headaches, colds, diarrhea, hepatitis, and bronchitis. A new $\delta$-truxinate derivative, ethyl, methyl 3,4,3', $4^{\prime}$-tetrahydroxy- $\delta$-truxinate (1), was isolated from the ethyl acetate extract of the entire plant, along with 4 known compounds. The antioxidant activity of these 5 compounds was determined by ABTS radical scavenging assay. Compound $\mathbf{1}$ was also tested for its cytotoxicity effect against HepG2 by MTT assay $\left(\mathrm{IC}_{50}=60 \mu \mathrm{M}\right)$, and its potential anti-inflammatory, antibiotic, and antitumor bioactivities were predicted using target fishing method software.

\section{Introduction}

Elephantopus is a genus comprised of about 30 species worldwide, mainly distributed in South America, with only 2 species E. scaber and E. tomentosus found in Southwest China [1]. From 2008 to 2012, our ethnobotanical investigation in the traditional medicinal market, held during the DragonBoat Festival in the fifth month of the Chinese lunar calendar with a history of over 700 years, found that Elephantopus scaber L. (Asteraceae) is a common medicinal plant used by the Zhuang people in Jingxi County of Southwest China. The local Zhuang people use E. scaber commonly as a traditional herbal medicine to treat many ailments including headaches, colds, diarrhea, hepatitis, and bronchitis.

To date, 30 compounds have been reported from $E$. scaber, including 4 sesquiterpene lactones, 9 triterpenes, and 5 flavones. Previous bioactivity studies on E. scaber demonstrated that the extracts or compounds from this species have antibiosis, antivirus, and cytotoxicity activities [2]. The sesquiterpene lactones in particular have been explored for their anti-inflammatory and hepatoprotective activities [3], which partially proved the traditional knowledge of E. scaber.

In this paper, the isolation and structure elucidation of a new ethyl, methyl $3,4,3^{\prime}, 4^{\prime}$-tetrahydroxy- $\delta$-truxinate $(\mathbf{1}$, Figure 1) is reported, together with 4 known compounds, 5O-caffeoylquinic acid (2) [4], chlorogenic acid methyl ester (3) [5], deoxyelephantopin (4), and isoscarbertopin (5) [6]. The radical scavenging activity of these 5 compounds was conducted using the ABTS method. The cytotoxicity effect against HpeG2 cell line of the new compound was determined by MTT assay, and the $\mathrm{IC}_{50}$ value $(24.0 \mu \mathrm{g} / \mathrm{mL})$ was obtained. In addition, the potential activity of $\mathbf{1}$, calculated with target fishing, which used 3D structures of compounds to identify their interacting proteins by virtual screening [7], is also presented.

\section{Materials and Method}

2.1. Plant Material. The whole plant of E. scaber was collected from the traditional medicinal market during the 
<smiles>COC(=O)[C@H]1[C@@H](c2ccc(O)c(O)c2)[C@H](C(=O)OC[Al])[C@]1(I)c1ccc(O)c(O)c1</smiles>

1<smiles>COC(=O)[C@@]1(O)CC(OC(=O)/C=C/c2ccc(O)c(O)c2)[C@@H](O)[C@H](O)C1</smiles>

2<smiles>O=C(/C=C/c1ccc(O)c(O)c1)OC1C[C@](O)(C(=O)O)C[C@H](O)[C@H]1O</smiles>

3<smiles>C=C(C)C(=O)OC(CC1=C[C@@H]2CC(C)=C[C@@H]1OC(=O)C2=C)C1OC(=O)C1=C</smiles>

4<smiles>C/C=C(/C)C(=O)OC1CC2=C[C@@H](C/C(C)=C/[C@@H]3OC(=O)C(C)C13)OC2=O</smiles>

5

Figure 1: The chemical structures of compounds obtained from Elephantopus scaber.

Dragon-Boat Festival of Jingxi County (Guangxi), Southwest China, and identified by Professor Chunlin Long. A voucher specimen was deposited in the Herbarium of Minzu University of China, numbered 201006023.

2.2. Extraction and Isolation. The air-dried and ground whole plant of E. scaber $(4.0 \mathrm{~kg})$ was extracted with $\mathrm{EtOH}: \mathrm{H}_{2} \mathrm{O}$ $(90: 10)$ at reflux for $3 \times 3 \mathrm{~h}$. The solvent was evaporated under reduced pressure to yield dark brown material (372.4 g). The latter was suspended in $\mathrm{H}_{2} \mathrm{O}(3 \mathrm{~L})$ and individually partitioned with petroleum ether $(3 \times 3 \mathrm{~L})$, Chloroform $(2 \times 3 \mathrm{~L})$, EtOAc $(3 \times 3 \mathrm{~L})$, and $n$ - $\mathrm{BuOH}(3 \times 3 \mathrm{~L})$ to obtain petroleum ether (169.4 g), Chloroform (33.8 g), EtOAc (46.9 g), and $n$ $\mathrm{BuOH}$ (122.3 g) phase.

The EtOAc phase was separated by silica gel column chromatography (CC) eluted with $\mathrm{CHCl}_{3}: \mathrm{CH}_{3} \mathrm{OH}$ in order of increasing polarity to give seven fractions on the basis of TLC. Fraction 3 was subjected to MCI CC eluted with $\mathrm{CH}_{3} \mathrm{OH}: \mathrm{H}_{2} \mathrm{O}$ to seven fractions $\mathrm{A}_{1}-\mathrm{A}_{7}$. Fraction $\mathrm{A}_{1}$ was isolated by Sephadex LH-20, ODS CC $\left(\mathrm{CH}_{3} \mathrm{OH}: \mathrm{H}_{2} \mathrm{O}=\right.$ $44: 56)$, and $\mathrm{Si}$ gel $\mathrm{CC}\left(\mathrm{CHCl}_{3}: \mathrm{CH}_{3} \mathrm{OH}=14: 1\right)$ successively to afford compound $\mathbf{1}(24.0 \mathrm{mg})$. Fraction $\mathrm{A}_{2}$ was purified with Sephadex LH-20 to give six subfractions. Subfraction 2 was subjected to ODS $\mathrm{CC}\left(\mathrm{CH}_{3} \mathrm{OH}: \mathrm{H}_{2} \mathrm{O}=30: 70\right)$ and silica gel $\mathrm{CC}\left(\mathrm{CHCl}_{3}: \mathrm{CH}_{3} \mathrm{OH}=12: 1\right)$ successively to give compound 3 (17.0 mg). Subfraction 3 was subjected to ODS $\mathrm{CC}\left(\mathrm{CH}_{3} \mathrm{OH}: \mathrm{H}_{2} \mathrm{O}=48: 52\right)$ and Sephadex LH-20 to afford compound 2 (27.0 $\mathrm{mg})$.

The petroleum ether phase was separated by silica gel CC eluted with petroleum ether: EtOAc (100:1-0:100) to give ten fractions. Fraction 8 was purified by MCI CC using $\mathrm{CH}_{3} \mathrm{OH}: \mathrm{H}_{2} \mathrm{O}(60: 100-100: 0)$ to afford four fractions $\mathrm{B}_{1}-$ $\mathrm{B}_{4}$. Fraction $\mathrm{B}_{2}$ was subjected to Sephadex LH-20 and ODS $\mathrm{CC}\left(\mathrm{CH}_{3} \mathrm{OH}: \mathrm{H}_{2} \mathrm{O}=83: 17\right)$ to give compound 4 (9.0 mg).
Fraction $\mathrm{B}_{3}$ was isolated by ODS CC $\left(\mathrm{CH}_{3} \mathrm{OH}: \mathrm{H}_{2} \mathrm{O}=80: 20\right)$ and Sephadex LH-20 to give compound $\mathbf{5}(7.0 \mathrm{mg})$.

2.3. Antioxidant Assay. The antioxidant activity of compounds 1-5 was evaluated with ABTS radical scavenging assay as described previously [8]. The $\mathrm{IC}_{50}$ was expressed as millimoles per liter (mM).

2.4. Cytotoxicity Assay. Compound 1 was tested for cytotoxicity using a slightly modified MTT method [9]. Briefly $150 \mu \mathrm{L}$ $(10 \mu \mathrm{M}, 20 \mu \mathrm{M}, 30 \mu \mathrm{M}$, and $40 \mu \mathrm{M})$ of samples was added to 96-well plate containing a confluent HepG2 cell monolayer in sextuplicate; $10 \mu \mathrm{g} / \mathrm{mL}$ of norcantharidin (NCTD) and blank medium were used as the positive and control group, respectively. After a $72 \mathrm{~h}$ incubation at $37^{\circ} \mathrm{C}, 100 \mu \mathrm{L}$ MTT solution $(5 \mathrm{mg} / \mathrm{mL}$ phosphate buffered saline) was added to each well, which was further incubated for $4 \mathrm{~h}$ for the formation of the formazan product. After removing the medium, $150 \mu \mathrm{L}$ DMSO was added to dissolve the formazan crystals. The optical density (OD) was measured at $550 \mathrm{~nm}$ with a microplate reader. The rate of inhibition was calculated by the following formula: rate of inhibition $=(1-$ sample OD)/control OD. The concentration causing inhibition of viable cells by $50 \%\left(\mathrm{IC}_{50}\right)$ was determined from a doseresponse curve, which was based on triplicate measurements.

2.5. Virtual Screening. The potential activity of compound 1 was predicted by the "Target Fishing" functional model software (Discovery Studio). The target fishing process was conducted as follows. The DockScore energy function was utilized to minimize the energy of compound 1 conformation. Setting full minimization as minimization gave the smart conformation of compound $\mathbf{1}$. Then, pharmacophore search 
was set to be screened and profiled. Screen and profile was set to be ligand profiler. PharmaDB pharmacophores were set to be all. Conformation generation was set to be the best. Maximum conformation was set to be 200. Energy threshold was set to be 10. Saved conformations were set to be true, and other parameters were set to be default.

Top 14 candidate receptors were ranked according to the fit value (as shown in Table 2), which is based on force field approximation and specifically examined the compound internal energy and the compound-receptor interaction energy, which is taken as the sum of van der Waal force and electrostatic energy [10].

2.6. Ethyl, Methyl 3,4,3',4'-tetrahydroxy- $\delta$-truxinate. Light yellow oil; $[\alpha]_{D}-2.0^{\circ}$ (c 0.018, MeOH); UV (in MeOH): $\lambda_{\max }$ 284 and $228 \mathrm{~nm}$; IR $v_{\max } \operatorname{ATR}\left(\mathrm{cm}^{-1}\right): 3436,2924,2854,1736$, and 1600-1450; HRESIMS ( $\mathrm{m} / \mathrm{z}): 403.1286[\mathrm{M}+\mathrm{H}]^{+} ;{ }^{1} \mathrm{H}$ NMR $\left(300 \mathrm{MHz}, \mathrm{CD}_{3} \mathrm{OD}\right): \delta_{\mathrm{H}} 6.73(4 \mathrm{H}, \mathrm{d}-$ like $), 6.62(1 \mathrm{H}, \mathrm{t}, J=6.0$, $3.0 \mathrm{~Hz}), 6.59(1 \mathrm{H}, \mathrm{t}, J=6.0,3.0 \mathrm{~Hz}), 4.19(2 \mathrm{H}, \mathrm{q}, J=7.1 \mathrm{~Hz})$, $3.73(3 \mathrm{H}, \mathrm{s}), 3.43(1 \mathrm{H}, \mathrm{d}$-like, $J=2.9 \mathrm{~Hz}), 3.40(1 \mathrm{H}, \mathrm{d}$-like, $J$ $=2.5 \mathrm{~Hz}), 3.30(1 \mathrm{H}, \mathrm{d}$-like, $J=3.1 \mathrm{~Hz}), 3.27(1 \mathrm{H}, \mathrm{d}$-like, $J=$ $3.5 \mathrm{~Hz})$, and $1.26(3 \mathrm{H}, \mathrm{t}, J=14.2,7.1 \mathrm{~Hz}) .{ }^{13} \mathrm{C}$ NMR $(75 \mathrm{MHz}$, $\left.\mathrm{CD}_{3} \mathrm{OD}\right): \delta_{\mathrm{C}} 173.5,173.0,145.0,144.1,132.8,117.6,115.0,113.5$, $60.7,51.2,50.2,50.0,46.2,45.8$, and 13.2.

\section{Results}

Compound 1 ( $28.0 \mathrm{mg}$ ) was separated from the ethyl acetate extract of E. scaber whole plant as a light yellow oil. The molecular formula $\mathrm{C}_{21} \mathrm{H}_{22} \mathrm{O}_{8}$ was determined by the molecular ion observed at $m / z 403.1359[\mathrm{M}+\mathrm{H}]^{+}$in the LC-TOF-MS (positive mode), which requires 11 degrees of unsaturation. The IR spectrum presented bands in the $1600-1450 \mathrm{~cm}^{-1}$, $1736 \mathrm{~cm}^{-1}, 2854 \mathrm{~cm}^{-1}, 2924 \mathrm{~cm}^{-1}$, and $3436 \mathrm{~cm}^{-1}$ region, which corresponded to aromatic, ester, methyl or methylene, and phenolic hydroxyl groups, respectively. The structure of compound 1 was further elucidated by examination of its $1 \mathrm{D}$ ${ }^{13} \mathrm{C}(75 \mathrm{MHz})$, DEPT $\left(90^{\circ}\right.$ and $\left.135^{\circ}\right)$, and ${ }^{1} \mathrm{H}(300 \mathrm{MHz}) \mathrm{NMR}$ spectra and HMQC, HMBC, COSY, and NOESY spectra in $\mathrm{MeOH}-d_{4}$. Only 13 carbon resonance signals and the other two carbon signals overlapped by the solvent carbon signals were found in ${ }^{13} \mathrm{C}$ NMR and DEPT spectra, respectively, which suggested that there are many identical parts in this molecule. Further analysis of the ${ }^{13} \mathrm{C}$ NMR spectrum of compound 1 suggested each signal of $\delta_{\mathrm{C}}$ 145.0, 144.1, 132.8, $117.6,115.0$, and 113.5 is comprised of two overlapping carbon signals $\left[\delta_{\mathrm{C}} 145.0\left(\mathrm{C}-3\right.\right.$ and $\left.\mathrm{C}-3^{\prime}\right), 144.1\left(\mathrm{C}-4\right.$ and $\left.\mathrm{C}-4^{\prime}\right), 132.8$ (C-1 and C-1' $), 117.6\left(\mathrm{C}-6\right.$ and $\left.\mathrm{C}-6^{\prime}\right), 115.0\left(\mathrm{C}-5\right.$ and $\left.\mathrm{C}-5^{\prime}\right)$, and $113.5\left(\mathrm{C}-2\right.$ and $\left.\mathrm{C}-2^{\prime}\right)$ ]; the other signals were assigned to two carbonyl carbon atoms $[\delta 173.5$ (C-9) and 173.0 (C$\left.9^{\prime}\right)$ ], one methoxy group $\left(\delta_{\mathrm{C}} 60.7, \mathrm{C}-10\right)$, one submethoxy $\left(\delta_{\mathrm{C}} 51.2, \mathrm{C}-10^{\prime}\right)$, methyl $\left(\delta_{\mathrm{C}} 13.2, \mathrm{C}-11^{\prime}\right)$, and four methine carbons $\left[\delta_{\mathrm{C}} 50.2\left(\mathrm{C}-7^{\prime}\right), 50.0(\mathrm{C}-7), 46.2\left(\mathrm{C}-8^{\prime}\right)\right.$, and $45.8(\mathrm{C}-$ $8)]$. From the number of unsaturations and carbons, these four methane carbons were deduced to be cyclobutane ring. From the analysis of ${ }^{1} \mathrm{H}$ NMR spectrum of compound 1 , two phenylpropanoid units were presented at $\delta_{\mathrm{H}} 6.73(4 \mathrm{H}$, d-like, $\left.\mathrm{H}-2, \mathrm{H}-5, \mathrm{H}-2^{\prime}, \mathrm{H}-5^{\prime}\right), \delta_{\mathrm{H}} 6.62(1 \mathrm{H}, \mathrm{t}, J=6.0,3.0 \mathrm{~Hz}, \mathrm{H}-$ $\left.6 / \mathrm{H}-6^{\prime}\right)$, and $6.59\left(1 \mathrm{H}, \mathrm{t}, J=6.0,3.0 \mathrm{~Hz}, \mathrm{H}-6^{\prime} / \mathrm{H}-6\right)$. Four
TABLE 1: The radical scavenging activity of 5 compounds from Elephantopus scaber.

\begin{tabular}{lcc}
\hline Compound & Name & $\mathrm{IC}_{50}(\mathrm{mM})^{\mathrm{a}}$ \\
\hline $\mathbf{1}$ & Ethyl, methyl 3, 4, 3', & $0.44 \pm 0.039$ \\
$\mathbf{2}$ & $4^{\prime}$-tetrahydroxy- $\delta$-truxinate & $0.96 \pm 0.096$ \\
$\mathbf{3}$ & 5-O-caffeoylquinic acid & $0.89 \pm 0.140$ \\
$\mathbf{4}$ & Chlorogenic acid methyl ester & $\mathrm{NR}$ \\
$\mathbf{5}$ & Deoxyelephantopin & $\mathrm{NR}$ \\
$\mathbf{6}^{\mathrm{b}}$ & Isoscarbertopin & $1.33 \pm 0.187$ \\
\hline
\end{tabular}

${ }^{a}$ The inhibition was recorded at $10 \mathrm{~min}$ of reaction (ABTS method) and $\mathrm{IC}_{50}$ value was measured using PROBIT model: $\operatorname{PROBIT}(p)=$ intercept + $B X$ (covariates $X$ are transformed using the base 10.000 logarithm). Each value corresponds to the mean and standard deviation of duplicates at five concentrations.

${ }^{\mathrm{b}}$ Positive control group.

NR: No reaction at the conditions discribed.

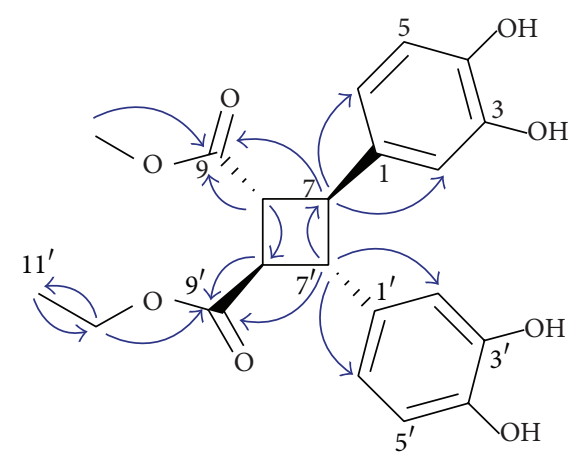

FIgURE 2: Selected HMBC (proton to carbon) correlations of compound 1 .

methane carbons of the cyclobutane ring were observed at $\delta_{\mathrm{H}} 3.43(1 \mathrm{H}, \mathrm{d}$-like, $J=2.9 \mathrm{~Hz}, \mathrm{H}-7), 3.40(1 \mathrm{H}, \mathrm{d}$-like, $J=$ $\left.2.5 \mathrm{~Hz}, \mathrm{H}-7^{\prime}\right), 3.30\left(1 \mathrm{H}, \mathrm{d}-\mathrm{like}, J=3.1 \mathrm{~Hz}, \mathrm{H}-8^{\prime}\right)$, and 3.27 $(1 \mathrm{H}, \mathrm{d}$-like, $J=3.5 \mathrm{~Hz}, \mathrm{H}-8)$, and the relative configuration of the cyclobutane ring was determined by comparing the chemical shift of compound 1 with reported ${ }^{1} \mathrm{H}$ NMR data of other $\delta$-truxinate derivatives [11]. Other signals of ${ }^{1} \mathrm{H}$ NMR spectra were assigned to submethoxy $\left[\delta_{\mathrm{H}} 4.19(2 \mathrm{H}, \mathrm{q}, J=\right.$ $\left.\left.7.1 \mathrm{~Hz}, \mathrm{H}-10^{\prime}\right)\right]$, methoxy $\left[\delta_{\mathrm{H}} 3.73(3 \mathrm{H}, \mathrm{s}, \mathrm{H}-10)\right]$, and methyl $\left[\delta_{\mathrm{H}} 1.26\left(3 \mathrm{H}, \mathrm{t}, J=14.2,7.1 \mathrm{~Hz}, \mathrm{H}-11^{\prime}\right)\right]$. Meanwhile, the HMBC spectrum of compound 1 presented the correlations from $\mathrm{H}$ 10 to $\mathrm{C}-9, \mathrm{H}-8$ to $\mathrm{C}-9$ and $\mathrm{C}-8^{\prime}, \mathrm{H}-7$ to $\mathrm{C}-2$ and $\mathrm{C}-6, \mathrm{H}-11^{\prime}$ to $\mathrm{C}-$ $10^{\prime}$, from $\mathrm{C}-10^{\prime}$ to $\mathrm{H}-9^{\prime}$ and $\mathrm{H}-11^{\prime}$, from $\mathrm{C}-8^{\prime}$ to $\mathrm{C}-9^{\prime}$, and from C-7' to H-2 ${ }^{\prime}$ and $\mathrm{H}-6^{\prime}$, respectively (Figure 2). Consequently, the structure of compound $\mathbf{1}$ was deduced to be ethyl, methyl $3,4,3^{\prime}, 4^{\prime}$-tetrahydroxy- $\delta$-truxinate, which was further confirmed by HMQC, COSY, and NOESY spectra. This paper reports a new $\delta$-truxinate derivative in Elephantopus genus for the first time. Compounds $\mathbf{2}-\mathbf{5}$ were identified, respectively, as 5-O-caffeoylquinic acid (2), chlorogenic acid methyl ester (3), deoxyelephantopin (4), and isoscarbertopin (5) by comparing their NMR and MS data with reported literature values.

The antioxidant activity of 5 compounds isolated from E. scaber was evaluated by the ABTS radical scavenging assay, and the results are presented as $\mathrm{IC}_{50}$ in Table 1 . 
TABLE 2: The potential bioactivity screening results of compound $\mathbf{1}$.

\begin{tabular}{|c|c|c|c|c|c|}
\hline Pharmacophore & Name of pharmacophore & Type & Fit value & Biological function(s) & Reference \\
\hline 2zb8-01-s & Prostaglandin reductase 2 & Protein & 4.05271 & Inflammation & {$[14]$} \\
\hline $3 \mathrm{kjs}-01$ & $\begin{array}{l}\text { Dihydrofolate reductase-thymidylate } \\
\text { synthase }\end{array}$ & Protein & 3.9615 & $\begin{array}{c}\text { Malarial parasites, anticancer, and } \\
\text { inflammation }\end{array}$ & [15-17] \\
\hline 2uue-01 & Cell division protein kinase 2 & Protein & 3.60758 & Cell division & {$[18,19]$} \\
\hline $2 \mathrm{w} 4 \mathrm{i}-01-\mathrm{s}$ & Glutamate racemase & Protein & 3.55547 & Antibiotics & {$[20-24]$} \\
\hline $3 \mathrm{k} 61-01$ & Peptide deformylase & Protein & 3.51102 & Antibiotic & {$[25,26]$} \\
\hline $3 \mathrm{md} 7-01$ & beta-lactamase-like & Protein & 3.41887 & Antibiotic & {$[27,28]$} \\
\hline $20 v y-01$ & Phosphodiesterase 10A & Protein & 3.41834 & $\begin{array}{l}\text { Schizophrenia and } \\
\text { nervous system }\end{array}$ & {$[29-31]$} \\
\hline $3 a c 8-01$ & Protooncogene tyrosine-protein kinase LCK & Protein & 3.39142 & Antitumor & {$[32,33]$} \\
\hline $3 f 7 z-01$ & G17 glycogen synthase kinase-3-beta & Protein & 3.30076 & Antitumor and neurodegenerative disease & {$[34]$} \\
\hline 3 cgy-01 & Virulence sensor histidine kinase phoQ & Protein & 3.28695 & Antibiotic & {$[35,36]$} \\
\hline 2qe5-01 & RNA-directed RNA polymerase & Protein & 3.28198 & Antivirus & {$[37,38]$} \\
\hline $1 \mathrm{dvx}-01$ & Transthyretin & Protein & 3.27421 & Antitumor and obesity & {$[39,40]$} \\
\hline $2 \mathrm{brc}-01$ & $\begin{array}{l}\text { ATP-dependent molecular chaperone } \\
\text { HSP90 }\end{array}$ & Protein & 3.26648 & Antitumor and antivirus & {$[41,42]$} \\
\hline $1 c 1 b-01-s$ & HIV-1 reverse transcriptase (A-chain) & Protein & 3.25549 & Anti-HIV & {$[43-45]$} \\
\hline
\end{tabular}

The most active radical scavengers were the new compound ethyl, methyl $3,4,3^{\prime}, 4^{\prime}$-tetrahydroxy- $\delta$-truxinate $\left(\mathrm{IC}_{50}=\right.$ $0.44 \pm 0.039 \mathrm{mM})$. The other 2 quinic acid derivatives 5-Ocaffeoylquinic acid and chlorogenic acid methyl ester also showed radical scavenging potential $\left(\mathrm{IC}_{50}=0.96 \pm 0.096\right.$ and $0.89 \pm 0.140 \mathrm{mM}$, resp.), while the antioxidant activity of the other 2 sesquiterpene lactone compounds deoxyelephantopin and isoscabertopin was not detected. Comparing the structures of these 5 compounds, the different antioxidant activities were attributed to the existence of phenolic hydroxyl groups in compounds, which were supported by the previous reports [12].

Compound $\mathbf{1}$ was also tested for in vitro cytotoxicity against HepG2 cell line with norcantharidin (NCTD, $60 \mu \mathrm{M}$ ) as positive control at $72 \mathrm{~h}$ incubation (Figure 3 ). Compound 1 exhibited a dose-response inhibition curve from $27 \%$ growth inhibition at $10 \mu \mathrm{g} / \mathrm{mL}$ to $81 \%$ at $40 \mu \mathrm{g} / \mathrm{mL}$, demonstrating that it has significant and dose-dependent inhibition on the growth of HepG2 $\left(\mathrm{IC}_{50}=60 \mu \mathrm{M}\right)$. Further work will be conducted on the mechanism by which compound 1 induces apoptosis.

With the rapid development of computer-aided drug design (CADD), virtual screening technique has been used more and more widely in drug design and bioactivity screening of compounds [13]. The potential bioactivities of compound 1 have been predicted by the target fishing method which was based on the Discovery Studio software and Protein Date Bank (PDB) including over twelve thousand 3D macromolecular structure data determined experimentally by X-ray crystallography and NMR. The top 14 biological molecular targets ranked as the fit value (FV) are reported (Table 2).

Theoretically, FV $>3$ means this target should be explored experimentally. The strongest activity of compound $\mathbf{1}$ was predicted to be anti-inflammatory $(\mathrm{FV}=4.05271)$ and antiAIDS (FV $=3.25549$ ), respectively (Table 2 ). Further experiments on the biological functions of $\mathbf{1}$ should be directed

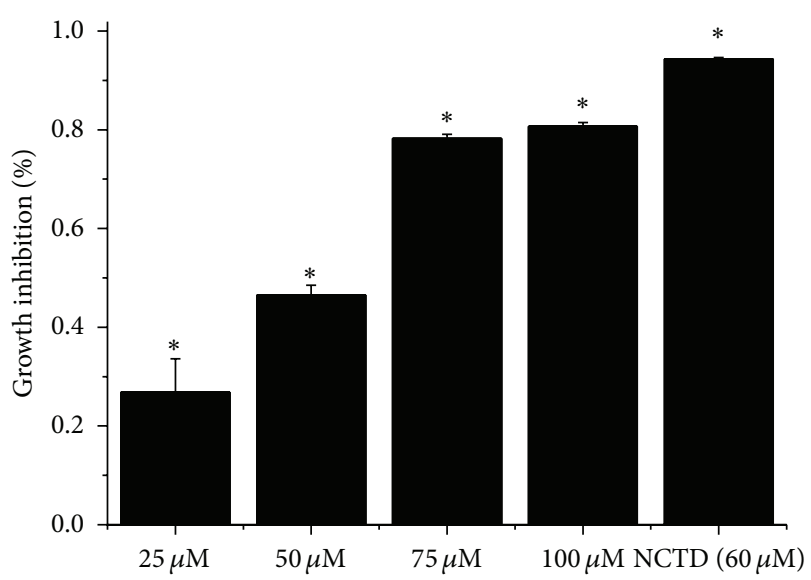

FIgURE 3: Growth inhibition of compound $\mathbf{1}$ on HepG2 cell lines, where each value represents mean \pm standard deviation of 6 replicates $(n=6)$, as compared to the positive control norcantharidin $(60 \mu \mathrm{M})\left({ }^{*} P<0.001\right.$ for comparison of control cell with cells treated with compound 1 and NCTD); $72 \mathrm{~h}$ for the incubation period of cells after being treated with compound $\mathbf{1}$ and NCTD.

towards its potential anti-inflammatory, antibiotic, antivirus, and anticancer activities.

\section{Discussion and Conclusion}

With more and more present modern drugs discovered from traditional medical knowledge, the traditional knowledge is getting more extensive attention, which also led to the development of important drugs such as reserpine (a treatment for hypertension) podophyllotoxin (the base of an important anticancer drug), and vinblastine (used in the treatment of certain cancers) [46].

Previous studies showed that pulmonary oxidant stress can cause some disease conditions, such as acute lung injury, 
radiation injury, COPD (chronic obstructive pulmonary disease), and inflammation [47]. Meanwhile, previous clinical and experimental studies described that antioxidant supplementation including flavonoids and vitamins may inverse the oxidant-mediated cough depression by modulating the inflammatory process in lung disease $[48,49]$. Interestingly, our work using ABTS assay demonstrated that compounds 1-3 showed strong antioxidant activity, especially compound $1\left(\mathrm{IC}_{50}=0.44 \pm 0.039 \mathrm{mM}\right)$. Moreover, E. scaber was also reported as the source of a number of sesquiterpene lactones, such as compounds 4 and 5, which have shown significant contribution to the anti-inflammatory activity of plants [50]. Some of the sesquiterpenes from the genus Elephantopus have demonstrated significant anti-inflammatory as well as hepatoprotective activities and are being considered as drug lead compounds [3]. Based on the above analysis, we hypothesize that Zhuang people use this plant to treat headaches, bronchitis, and hepatitis, due to its anti-inflammatory and antioxidant effects.

According to the in vitro cytotoxicity assay with NCTD $(60 \mu \mathrm{M})$ as control group and activity virtual screening, compound 1 exhibited good $\left(\mathrm{IC}_{50}=60 \mu \mathrm{M}\right)$ and doseresponse inhibition on HepG2 cell line and potential antiinflammatory, antibiotic, antivirus, and anticancer activities, which indicated that the further research of E. scaber could be focused on anticancer and anti-inflammatory activity. The present work further developed the usage of this traditional medicine plant.

\section{Conflict of Interests}

The authors declare that there is no conflict of interests regarding the publication of this paper.

\section{Acknowledgments}

The authors thank Vanya Petrova (City University of New York) for assistance with the antioxidant assay and Weiguo Liu (Minzu University of China) for assistance with using the Discovery Studio software. This work was supported in part by the National Natural Science Foundation of China (31161140345 and 31070288), the Ministry of Science \& Technology of China (2012FY110300), the Ministry of Education of China through its 111 and 985 Projects (B08044, MUC9859, and MUC98506-01000101), and JSPS Asian Core program (JSPS/AP/109080).

\section{References}

[1] Z. Y. Wu and P. Raven, Flora of China, vol. 20-21 of Asteraceae, Science Press, Beijing, China; Missouri Botanical Garden, St. Louis, Mo, USA, 2007.

[2] J. J. Wang, Y. J. Liu, J. X. Xu, A. Wang, Y. L. Wang, and C. L. Long, "Studies on medicinal plants of Elephantopus (Compositae)," Natural Products Research and Development, vol. 25, pp. 401409, 2013.

[3] C. C. Huang, K. J. Lin, Y. W. Cheng, C. A. Hsu, S. S. Yang, and L. F. Shyur, "Hepatoprotective effect and mechanistic insights of deoxyelephantopin, a phyto-sesquiterpene lactone, against fulminant hepatitis," Journal of Nutritional Biochemistry, vol. 24, no. 3, pp. 516-530, 2013.

[4] K. Schütz, D. Kammerer, R. Carle, and A. Schieber, "Identification and quantification of caffeoylquinic acids and flavonoids from artichoke (Cynara scolymus L.) heads, juice, and pomace by HPLC-DAD-ESI/MSn," Journal of Agricultural and Food Chemistry, vol. 52, no. 13, pp. 4090-4096, 2004.

[5] X. Zhu, X. Dong, Y. Wang, P. Ju, and S. Luo, "Phenolic compounds from Viburnum cylindricum," Helvetica Chimica Acta, vol. 88, no. 2, pp. 339-342, 2005.

[6] Q. L. Liang and Z. D. Min, "Sesquiterpene lactones from Elephantopus scaber," Chinese Chemical Letters, vol. 13, no. 4, pp. 343-344, 2002.

[7] L. R. Wang and X. Q. Xie, "Computational target fishing: what should chemogenomics researchers expect for the future of in silico drug design and discovery?" Future Medicinal Chemistry, vol. 6, no. 3, pp. 247-249, 2014.

[8] S. B. Wu, K. Dastmalchhi, C. L. Long, and E. J. Kennelly, "Metabolite profiling of jaboticaba (Myrciaria cauliflora) and other dark-colored fruit juices," Journal of Agriculture and Food Chemistry, vol. 60, no. 30, pp. 7513-7525, 2012.

[9] A. L. Liu, H. D. Wang, S. M. Lee, Y. T. Wang, and G. H. Du, "Structure-activity relationship of flavonoids as influenza virus neuraminidase inhibitors and their in vitro anti-viral activities," Bioorganic and Medicinal Chemistry, vol. 16, no. 15, pp. 71417147, 2008.

[10] C. Y. C. Chen, "Virtual screening and drug design for PDE-5 receptor from traditional Chinese medicine database," Journal of Biomolecular Structure and Dynamics, vol. 27, no. 5, pp. 627640, 2010.

[11] Y. Deng, Y. W. Chin, H. B. Chai et al., "Phytochemical and bioactivity studies on constituents of the leaves of Vitex quinata," Phytochemistry Letters, vol. 4, no. 3, pp. 213-217, 2011.

[12] D. Huang, O. U. Boxin, and R. L. Prior, "The chemistry behind antioxidant capacity assays," Journal of Agricultural and Food Chemistry, vol. 53, no. 6, pp. 1841-1856, 2005.

[13] J. H. Nettles, J. L. Jenkins, A. Bender, Z. Deng, J. W. Davies, and M. Glick, "Bridging chemical and biological space: "target fishing" using 2D and 3D molecular descriptors," Journal of Medicinal Chemistry, vol. 49, no. 23, pp. 6802-6810, 2006.

[14] I. Inoue, S. I. Goto, K. Mizotani et al., "Lipophilic HMGCoA reductase inhibitor has an anti-inflammatory effect: reduction of MRNA levels for interleukin-1 $\beta$, interleukin-6, cyclooxygenase-2, and $\mathrm{p} 22$ phox by regulation of peroxisome proliferator-activated receptor $\alpha(\mathrm{PPAR} \alpha)$ in primary endothelial cells," Life Sciences, vol. 67, no. 8, pp. 863-876, 2000.

[15] B. I. Schweitzer, A. P. Dicker, and J. R. Bertino, "Dihydrofolate reductase as a therapeutic target," The FASEB Journal, vol. 4, no. 8, pp. 2441-2452, 1990.

[16] L. Jiang, P. C. Lee, J. White, and P. K. Rathod, "Potent and selective activity of a combination of thymidine and 1843U89, a folate-based thymidylate synthase inhibitor, against Plasmodium falciparum," Antimicrobial Agents and Chemotherapy, vol. 44, no. 4, pp. 1047-1050, 2000.

[17] N. Sienkiewicz, S. Jarosławski, S. Wyllie, and A. H. Fairlamb, "Chemical and genetic validation of dihydrofolate reductasethymidylate synthase as a drug target in African trypanosomes," Molecular Microbiology, vol. 69, no. 2, pp. 520-533, 2008.

[18] L. A. Pinna and F. Meggio, "Protein kinase CK2 ("casein kinase-2") and its implication in cell division and proliferation," Progress in Cell Cycle Research, vol. 3, pp. 77-97, 1997. 
[19] S. Ortega, I. Prieto, J. Odajima et al., "Cyclin-dependent kinase 2 is essential for meiosis but not for mitotic cell division in mice," Nature Genetics, vol. 35, no. 1, pp. 25-31, 2003.

[20] M. Ashiuchi, K. Tani, K. Soda, and H. Misono, "Properties of glutamate racemase from Bacillus subtilis IFO 3336 producing poly- $\gamma$-glutamate," Journal of Biochemistry, vol. 123, no. 6, pp. 1156-1163, 1998.

[21] K. Y. Hwang, C. S. Cho, S. S. Kim, H. C. Sung, Y. G. Yu, and Y. Cho, "Structure and mechanism of glutamate racemase from Aquifex pyrophilus," Nature Structural Biology, vol. 6, no. 5, pp. 422-426, 1999.

[22] A. de Dios, L. Prieto, J. A. Martín et al., "4-substituted Dglutamic acid analogues: the first potent inhibitors of glutamate racemase (MurI) enzyme with antibacterial activity," Journal of Medicinal Chemistry, vol. 45, no. 20, pp. 4559-4570, 2002.

[23] G. S. Basarab, P. J. Hill, A. Rastagar, and P. J. H. Webborn, "Design of Helicobacter pylori glutamate racemase inhibitors as selective antibacterial agents: a novel pro-drug approach to increase exposure," Bioorganic and Medicinal Chemistry Letters, vol. 18, no. 16, pp. 4716-4722, 2008.

[24] B. Geng, G. Basarab, J. Comita-Prevoir et al., "Potent and selective inhibitors of Helicobacter pylori glutamate racemase (MurI): pyridodiazepine amines," Bioorganic and Medicinal Chemistry Letters, vol. 19, no. 3, pp. 930-936, 2009.

[25] C. M. Apfel, H. Locher, S. Evers et al., "Peptide deformylase as an antibacterial drug target: target validation and resistance development," Antimicrobial Agents and Chemotherapy, vol. 45, no. 4, pp. 1058-1064, 2001.

[26] J. A. Leeds and C. R. Dean, "Peptide deformylase as an antibacterial target: a critical assessment," Current Opinion in Pharmacology, vol. 6, no. 5, pp. 445-452, 2006.

[27] S. Kumar, U. Narain, S. Tripathi, and K. Misra, "Syntheses of curcumin bioconjugates and study of their antibacterial activities against $\beta$-lactamase-producing microorganisms," Bioconjugate Chemistry, vol. 12, no. 4, pp. 464-469, 2001.

[28] Q. Li, J. Y. Lee, R. Castillo et al., "NB2001, a novel antibacterial agent with broad-spectrum activity and enhanced potency against $\beta$-lactamase-producing strains," Antimicrobial Agents and Chemotherapy, vol. 46, no. 5, pp. 1262-1268, 2002.

[29] T. M. Coskran, D. Morton, F. S. Menniti et al., "Immunohistochemical localization of phosphodiesterase $10 \mathrm{~A}$ in multiple mammalian species," Journal of Histochemistry and Cytochemistry, vol. 54, no. 11, pp. 1205-1213, 2006.

[30] F. S. Menniti, T. A. Chappie, J. M. Humphrey, and C. J. Schmidt, "Phosphodiesterase $10 \mathrm{~A}$ inhibitors: a novel approach to the treatment of the symptoms of schizophrenia," Current Opinion in Investigational Drugs, vol. 8, no. 1, pp. 54-59, 2007.

[31] C. J. Schmidt, D. S. Chapin, J. Cianfrogna et al., "Preclinical characterization of selective phosphodiesterase 10A inhibitors: a new therapeutic approach to the treatment of schizophrenia," The Journal of Pharmacology and Experimental Therapeutics, vol. 325, no. 2, pp. 681-690, 2008.

[32] J. B. Bolen, R. B. Rowley, C. Spana, and A. Y. Tsygankov, “The Src family of tyrosine protein kinases in hemopoietic signal transduction," The FASEB Journal, vol. 6, no. 15, pp. 3403-3409, 1992.

[33] E. Buchdunger, J. Zimmermann, H. Mett et al., "Inhibition of the Abl protein-tyrosine kinase in vitro and in vivo by a 2 phenylaminopyrimidine derivative," Cancer Research, vol. 56, pp. 100-104, 1996.

[34] P. Mishra, S. Senthivinayagam, A. Rana, and B. Rana, "Glycogen synthase kinase- $3 \beta$ regulates snail and $\beta$-catenin during gastrin-induced migration of gastric cancer cells," Journal of Molecular Signaling, vol. 5, article 9, 2010.

[35] D. Beier and R. Gross, "Regulation of bacterial virulence by twocomponent systems," Current Opinion in Microbiology, vol. 9, no. 2, pp. 143-152, 2006.

[36] W. J. Gooderham, S. L. Gellatly, F. Sanschagrin et al., "The sensor kinase PhoQ mediates virulence in Pseudomonas aeruginosa," Microbiology, vol. 155, no. 3, pp. 699-711, 2009.

[37] T. Dalmay, A. Hamilton, S. Rudd, S. Angell, and D. C. Baulcombe, "An RNA-dependent RNA polymerase gene in Arabidopsis is required for posttranscriptional gene silencing mediated by a transgene but not by a virus," Cell, vol. 101, no. 5, pp. 543-553, 2000.

[38] F. Simmer, M. Tijsterman, S. Parrish et al., "Loss of the putative RNA-directed RNA polymerase RRF-3 makes C. elegans hypersensitive to RNAi," Current Biology, vol. 12, no. 15, pp. 1317-1319, 2002.

[39] L. H. Wu and C. T. Woodbridge, "Regulation of transthyretin to treat obesity," Patent Application publication 0160394 A1, 2002.

[40] S. K. Frey, J. Spranger, A. Henze, A. F. H. Pfeiffer, F. J. Schweigert, and J. Raila, "Factors that influence retinol-binding protein 4-transthyretin interaction are not altered in overweight subjects and overweight subjects with type 2 diabetes mellitus," Metabolism: Clinical and Experimental, vol. 58, no. 10, pp. 13861392, 2009.

[41] J. Hu and C. Seeger, "Hsp90 is required for the activity of a hepatitis B virus reverse transcriptase," Proceedings of the National Academy of Sciences of the United States of America, vol. 93, no. 3, pp. 1060-1064, 1996.

[42] J. R. Sydor, E. Normant, C. S. Pien et al., "Development of 17-allylamino-17-demethoxygeldanamycin hydroquinone hydrochloride (IPI-504), an anti-cancer agent directed against Hsp90," Proceedings of the National Academy of Sciences of the United States of America, vol. 103, no. 46, pp. 17408-17413, 2006.

[43] C. Tantillo, J. Ding, A. Jacobo-Molina et al., "Locations of anti-AIDS drug binding sites and resistance mutations in the three-dimensional structure of HIV-1 reverse transcriptase. Implications for mechanisms of drug inhibition and resistance," Journal of Molecular Biology, vol. 243, no. 3, pp. 369-387, 1994.

[44] S. G. Sarafianos, B. Marchand, K. Das et al., "Structure and function of HIV-1 reverse transcriptase: molecular mechanisms of polymerization and inhibition," Journal of Molecular Biology, vol. 385, no. 3, pp. 693-713, 2009.

[45] K. M. Frey, M. Bollini, A. C. Mislak et al., "Crystal structures of HIV-1 reverse transcriptase with picomolar inhibitors reveal key interactions for drug design," Journal of the American Chemical Society, vol. 134, no. 48, pp. 19501-19503, 2012.

[46] M. Idu, "Current trends in ethnobotany," Tropical Journal of Pharmaceutical Research, vol. 8, no. 4, pp. 295-296, 2009.

[47] M. Christofidou-Solomidou and V. R. Muzykantov, "Antioxidant strategies in respiratory medicine," Treatments in Respiratory Medicine, vol. 5, no. 1, pp. 47-78, 2006.

[48] M. Brozmanova, J. Plevkova, V. Bartos, L. Plank, M. Javorka, and M. Tatar, "The interaction of dietary antioxidant vitamins and oxidative stress on cough reflex in guinea-pigs after long term oxygen therapy," Journal of Physiology and Pharmacology, vol. 57, supplement 4, pp. 45-54, 2006.

[49] M. Brozmanova, V. Bartos, L. Plank, J. Plevkova, and M. Tatar, "Dietary intake of flavonoids and hyperoxia-induced oxidative stress related cough in guinea pigs," Bratislava Medical Journal, vol. 108, no. 12, pp. 489-494, 2007. 
[50] M. Chadwick, H. Trewin, F. Gawthrop, and C. Wagstaff, "Sesquiterpenoids lactones: benefits to plants and people," International Journal of Molecular Sciences, vol. 14, no. 6, pp. 1278012805, 2013. 


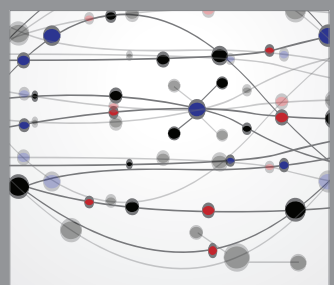

The Scientific World Journal
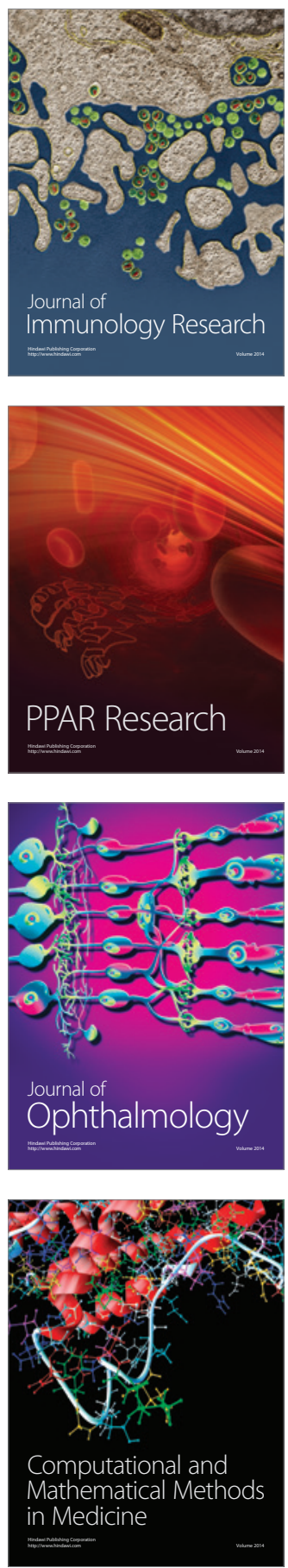

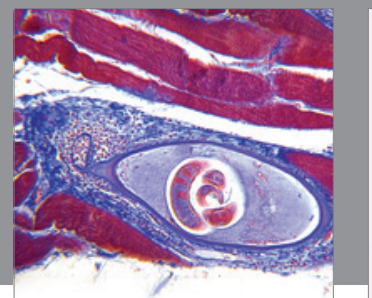

Gastroenterology

Research and Practice
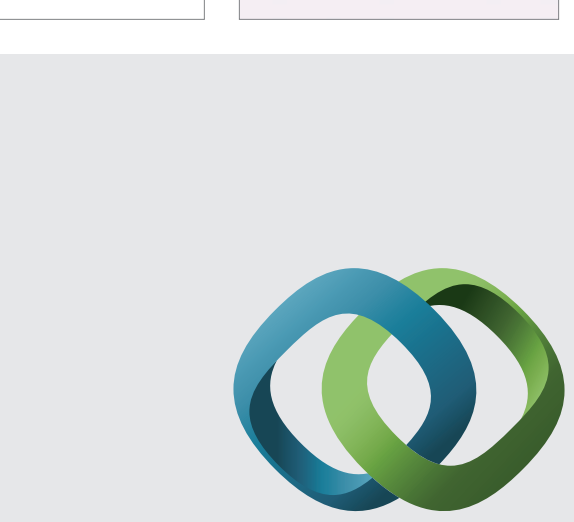

\section{Hindawi}

Submit your manuscripts at

http://www.hindawi.com
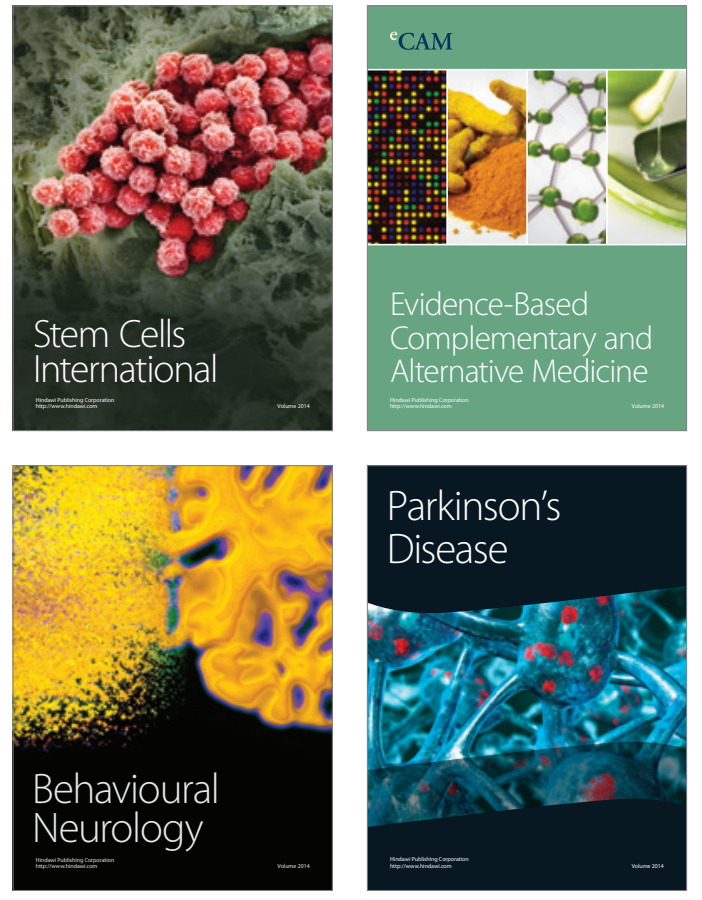
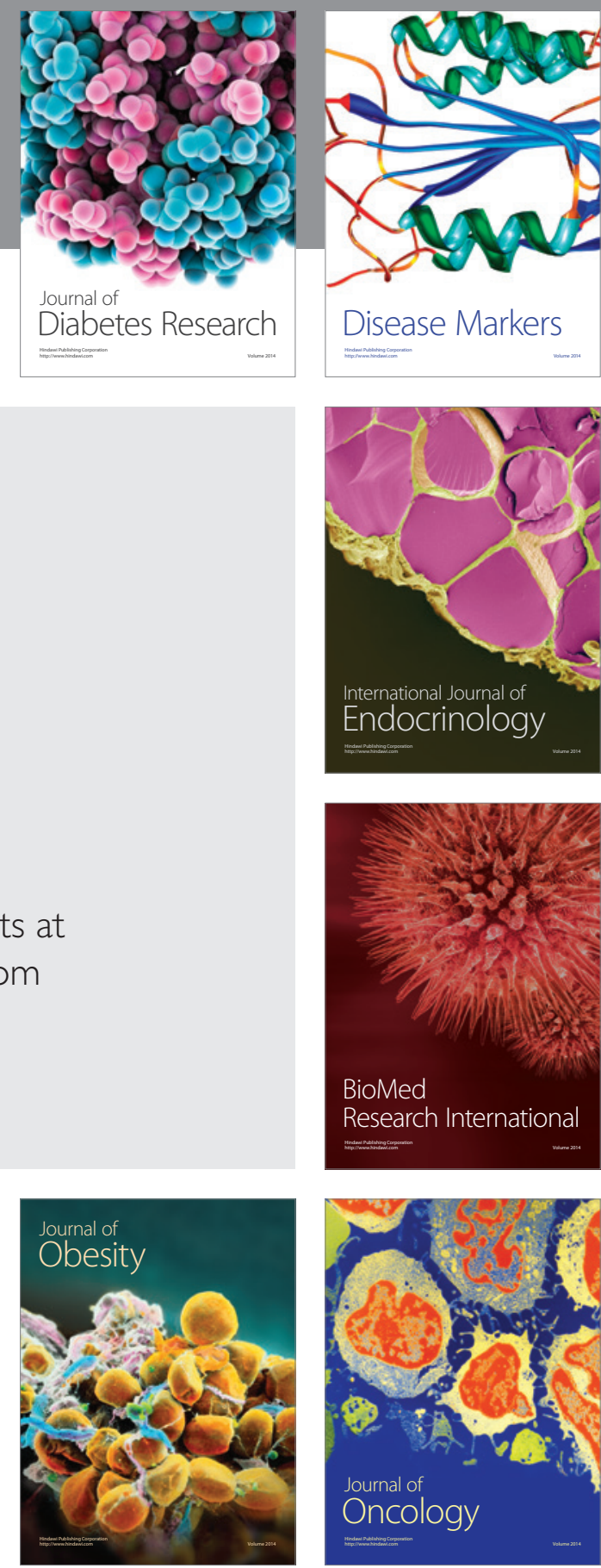

Disease Markers
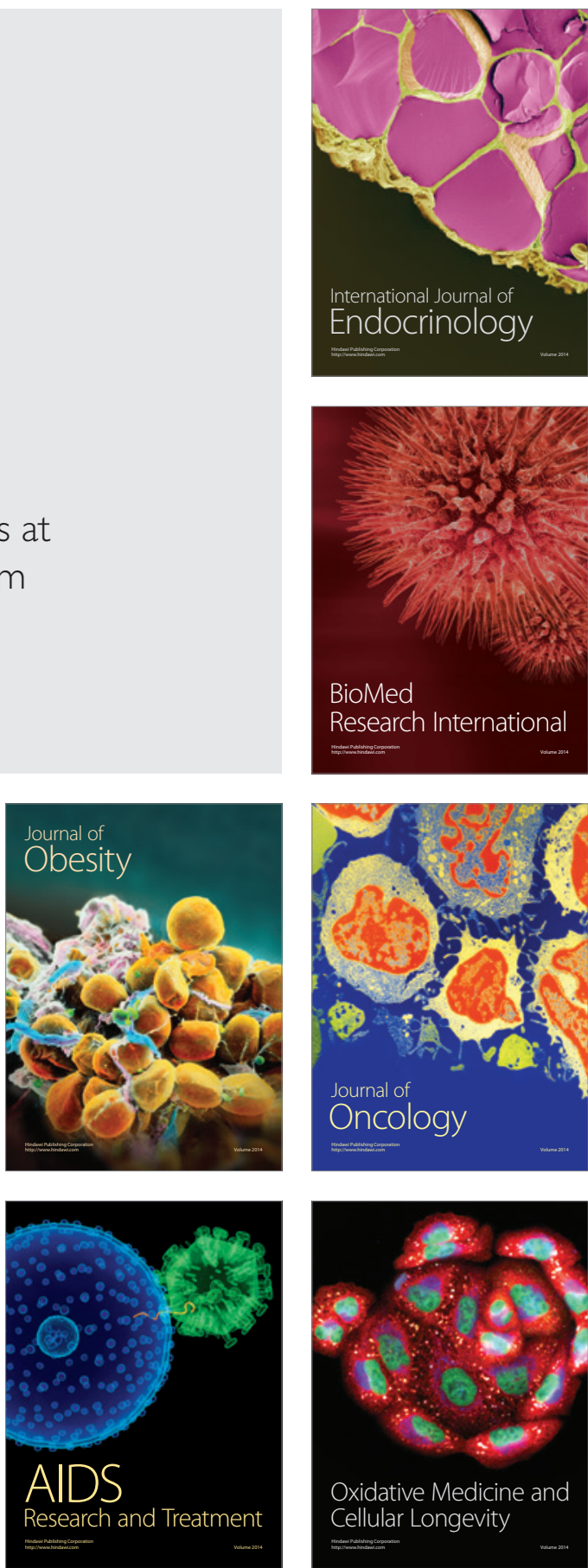